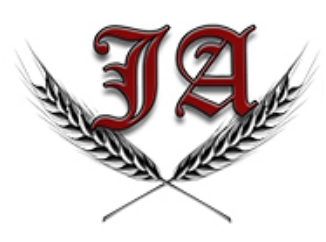

\section{JOURNAL of AGRICULTURE}

agrijournal@hotmail.com

ISSN: 2636-8757

https://dergipark.org.tr/tr/pub/ja

DOI: $10.46876 /$ ja.925218

Research /Araştırma

Determination of Chemical Properties of The Hot Springs Waters and Comparison of Bacteria: Hot Springs in The East and Southeast Anatolı Region of Turkey

Orhan ULUÇAY ${ }^{1 *}$, Arzu GÖRMEZ ${ }^{2}$, Cem ÖZİÇ ${ }^{3}$

\title{
ABSTRACT
}

Thermal hot water samples were collected in 2017 from six different hot springs from eastern and southeastern Turkey's (Agri, Van, Sirnak, Mardin, Siirt and Erzurum). During the study period, the analysis of various physicochemical properties of the water samples and the diversity of microorganisms in the hot springs were investigated. During the study period, eleven physico-chemical parameters such as water temperature, $\mathrm{pH}$, conductivity, nitrogen dioxide, ammonium, nitrate, iron, aluminum, copper, lead and sulfur were studied. Five different bacterial strains have been detected in one or more of different hot springs. The electrical conductivity (EC) was ranged from $942,8 \mathrm{mS} / \mathrm{cm}$ to $5,158 \mathrm{mS} / \mathrm{cm}$ in the water of the hot spring. The conductivity and $\mathrm{pH}$ value of only Hista thermal source were determined as $942.9(\mathrm{mS} / \mathrm{cm})$ and 9.1 . In all other sources the conductivity varied above $1000(\mathrm{mS} / \mathrm{cm})$ and the $\mathrm{pH}$ between 6.9 and 8.5 . The $\mathrm{NO}_{2}$ value ranges of the hot springs are determined as 0.254 to $0.613 \mathrm{mg} / \mathrm{L}$. The source temperatures of the hot spring water were determine minimum and maximum temperature values for Agri (Davut and Kopru), Erzurum (Pasinler), Van (Hasanabdal), Siirt (Hista), Mardin (Dargecit) and Sirnak (Guclukonak), (62-78 $\left.{ }^{\circ} \mathrm{C}\right),\left(40-46^{\circ} \mathrm{C}\right),\left(60-66^{\circ} \mathrm{C}\right)$, $\left(62-67^{\circ} \mathrm{C}\right),\left(59-62^{\circ} \mathrm{C}\right)$ and $\left(59-67^{\circ} \mathrm{C}\right)$ respectively. In terms of physical and chemical properties, it was observed that there are generally differences in the hot spring waters.

Keywords: Bacillus, Hot Springs, Physico-Chemical properties, Thermophilic, Hot water

\section{Türkiye'nin Doğu ve Güneydoğu Anadolu Bölgesindeki Kaplica Sularinin Kimyasal, Fiziksel ve Bakteriyel Özelliklerinin Araştirilmasi}

\section{ÖZET}

Türkiye'nin doğu ve güneydoğusundaki altı farklı kaplıcadan 2017 yılında (Ağrı, Van, Şırnak, Mardin, Siirt ve Erzurum) termal sıcak su örnekleri toplanmıştır. Çalışma süresince su örneklerinin çeşitli fizikokimyasal özelliklerinin analizi ve kaplıcalarda bulunan mikroorganizma çeşitliliği araştırılmıştır. Çalışma süresince su sıcaklığ $1, \mathrm{pH}$, iletkenlik, nitrojen dioksit, amonyum, nitrat, demir, alüminyum, bakır, kurşun ve kükürt gibi on bir fiziko-kimyasal parametre incelenmiştir. Beş farklı bakteri türü bir veya daha fazla farklı kaplıcada tespit edilmiştir. Kaplıca suyunun kaynak sıcaklıkları sırasıyla Ağrı (Davut ve Köprü), Erzurum (Pasinler), Van (Hasanabdal), Siirt (Hista), Mardin (Dargeçit) ve Şırnak (Güçlükonak) için minimum ve maksimum sicaklık değerleri $\left(62-78^{\circ} \mathrm{C}\right),\left(40-46^{\circ} \mathrm{C}\right),\left(60-66^{\circ} \mathrm{C}\right),\left(62-67^{\circ} \mathrm{C}\right),\left(59-62^{\circ} \mathrm{C}\right)$ ve $\left(59-67^{\circ} \mathrm{C}\right)$ olarak belirlendi. Kaplıca sularında fiziksel ve kimyasal özellikler bakımından da genel olarak farklılıklar gözlenildi.

Anahtar Kelimeler: Bacillus, Kaplıcalar, Fiziko-Kimyasal özellikler, Termofilik, Sıcak su

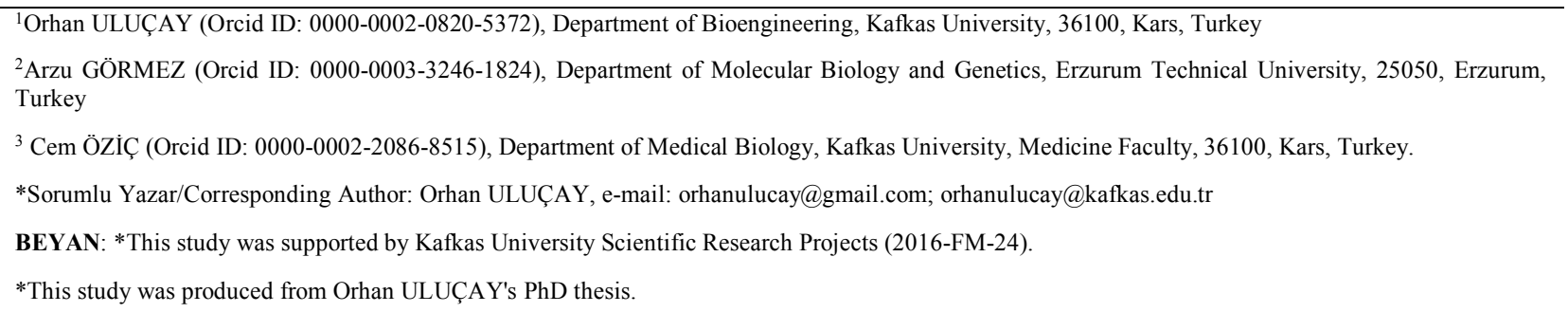




\section{INTRODUCTION}

Water, which is the most fundamental component of vital activities and a good solvent, can be exposed to physical and chemical changes and biological contamination and therefore, it can be the source of many diseases that can pose problems for living things (Donderici et al., 2010). Waters that accumulate at the depths of the soil suitable for geological conditions and come out spontaneously from an exit point are defined as spring water (Agaoglu et al., 1999). Turkey, a region which is rich in terms of hidrotermal and grabens, faults, volcanoes and alpine regions of the Himalayas and is in the zone of hydrothermal alteration (Simsek, 1997). Turkey's continental crust, Anatolia fragmented and have changed over time as the lower plate northward movement of the Arabian plate with the right place. These displacements allowed the entrance of magma in Eastern Anatolia, resulting in the emergence of volcanic formations such as Agri, Tendurek and Nemrut (Pasvanoglu, 2013; Saroglu et al., 1980; Sengor and Kidd, 1979). The chemical, physical and microbial diversity of thermal waters, especially the effect of water-rock interactions and the differences of waters in geothermal systems, have attracted the attention of researchers in recent years (Fournier, 1979; Mahon, 1970; Federica Valeriani et al., 2018; F. Valeriani et al., 2017).

Microorganisms can be found in almost all places in the world (mountains, volcanic rocks, deep sea waters, glaciers and so on) under very extreme conditions to survive. Microorganisms differ in terms of their growth and development by maintaining their vitality in varying temperature parameter ranges. When microorganisms that survive are categorized according to these parameters; They are classified psychrophils, mesophiles, thermophiles and hyperthermophiles (Baltaci et al., 2017). Thermophilic bacteria are common in soil, hot springs and volcanic habitats. Thermophilic bacteria are divided into 4 groups as moderate thermophiles $\left(50-60^{\circ} \mathrm{C}\right)$, extreme thermophiles $\left(65-80^{\circ} \mathrm{C}\right)$, hyperthermophiles $\left(80-110^{\circ} \mathrm{C}\right)$ and hyperthermophiles $\left(110^{\circ} \mathrm{C}\right.$ and above) (Oztas Gulmus and Gormez, 2020). Considering all these conditions, microorganisms that can survive in extremely hot conditions are known as extremophiles (Pathak and Rathod, 2014). Among extremophiles, thermophiles have attracted great attention from past to present because of their ability to survive very high temperatures; they are even active at a high temperature. In this respect, they are more resistant to both stable protein structures and various chemicals. Since thermophilic microorganisms can remain stable at very high temperatures in fields such as the pharmaceutical, food industry, paper industry and chemical industries, the enzymes of such microorganisms have also interested researchers (Ulucay, 2018).

Turkey has 133 pieces of thermal water is at a temperature of $40^{\circ} \mathrm{C}$ and above (Akkaya and Kivanc, 2009). Therefore, it is important to study these thermal water sources. In this context, in this study, it was aimed to determine of physical and chemical properties of water samples taken from different hot water sources. Thus, the physicochemical properties of the collected water samples were determined and compared with their biological contents obtained on our previous studies (Ulucay, 2018).

\section{MATERIAL AND METHODS}

\section{Study area}

In this study, the samples were examined taken from six different locations in the eastern and southeastern of Turkey. Agri (Davut and Kopru), Erzurum (Pasinler), Van (Hasanabdal), Siirt (Hista), Mardin (Dargecit) and, Sirnak (Guclukonak) are approximately 1925 m, 1869 m, 1890 m, 900 m, 940 $\mathrm{m}$ and, 950 meters above sea level, respectively (Ulucay, 2018). The highest temperature values of the hot spring waters were measured as approximately $78,46,66,67,62$ and $67^{\circ} \mathrm{C}$, respectively.

Water samples were collected from the exit points of hot water springs with autoclaved glass jars in June and July 2017.

\section{Physical and chemical structure of waters}


Water samples were analyzed for a pre-defined set of physical and chemical properties (Sample's conductivity, $\mathrm{NO}_{3}^{-1}$ (Nitrate), $\mathrm{NH}_{4}^{+1}$ (Ammonium), $\mathrm{NO}_{2}{ }^{-1}$ (Nitrite), $\mathrm{Fe}$ (Iron), $\mathrm{Al}^{+3}$ (Aluminum), $\mathrm{Cu}$ (Copper) and $\mathrm{Pb}$ (Lead) values) in the water analysis laboratory of the Kars Provincial Directorate of Public Health. The water temperature and $\mathrm{pH}$ were measured (Model No. AZ 8685) by carefully immersing the digital thermometer 5 to $10 \mathrm{~cm}$ in the hot water of the source and the readings were noted.

\section{Bacterial isolates}

The bacteria isolated from the same hot springs on our previous study were used in this study. Thereby, the physical and chemical properties of the thermal waters were correlated with these isolates (Ulucay, 2018).

\section{RESULTS AND DISCUSSION}

\section{Physical and chemical structure of waters}

The data of all ten physico-chemical properties got under the sampling process in June and July 2017 from the hot springs in six different locations are given in Table 1. The minimum and maximum temperature values: for Davut and Kopru, Pasinler, Hasanabdal, Hista, Dargecit and Guclukonak hot springs, $\left(62-78^{\circ} \mathrm{C}\right),\left(40-46^{\circ} \mathrm{C}\right),\left(60-66^{\circ} \mathrm{C}\right),\left(62-67^{\circ} \mathrm{C}\right),\left(59-62^{\circ} \mathrm{C}\right)$ and $\left(59-67^{\circ} \mathrm{C}\right)$ respectively. When the $\mathrm{pH}$ values of the water in the hot springs were examined, it was observed that the $\mathrm{pH}$ ranged from 6.9 to 9.1 . These $\mathrm{pH}$ results showed that some of the thermal spring waters are acidic and the others are basic. Similarly, when the literature is examined, the $\mathrm{pH}$ range has also been reported in other hot springs (Ghilamicael et al., 2017; Kumar and Sharma, 2019; Singh et al., 2015). The conductivity of water is a measure of the amount of electrolyte (total cation or anion) in the water. Conductivity value in water is closely related to the sum of dissolved solids and decreases with increasing temperature and increases in pollution. The presence of ammonium, possible bacterial cultures, sewage and livestock wastes in the waters are important parameters as an indicator of pollution. When looking at other parameters encountered in water, nitrate and nitrite found in nature are ions that are components of the nitrogen cycle. Considering the standard values in potable water, $\mathrm{pH}$, conductivity, nitrate, nitrite and ammonium levels are reported as $6.5-9.5,2500 \mu \mathrm{s} / \mathrm{cm}, 50 \mathrm{mg} / \mathrm{L}, 0.5 \mathrm{mg} / \mathrm{L}$ and $0.5 \mathrm{mg} / \mathrm{L}$, respectively (Cetin et al., 2016). In general, the electrical conductivity (EC) was ranged from 942,8 $\mathrm{mS} / \mathrm{cm}$ to $5,158 \mathrm{mS} / \mathrm{cm}$ in the water of the hot spring. Similarly, it was observed that the electrical conductivity values varying between 281.94 and 9108.4 in samples taken from seven different hot spring in Ethiopia thermal springs (Haki and Gezmu, 2012). In studies conducted in some hot springs in Turkey, it was also observed the differences in terms of these values. For example, it was observed that the electrical conductivity was between 222 and $5750(\mathrm{mS} / \mathrm{cm})$ in samples taken from thirteen different hot spring (Pasvanoglu, 2013). Aksoy et al. (2009) in their study; Examining the thermal water resources in the Balcova region in Turkey, it was determined that the conductivity values of all samples taken because of the examination were over $1000(\mathrm{mS} / \mathrm{cm})$ and when the values in groundwater are examined; they have determined that their $\mathrm{pH}$ is between 7 and 8.9. (Aksoy et al., 2008). The amount of carbonate, bicarbonate and carbon dioxide dissolved in the water also has an effect on the $\mathrm{pH}$ of the water. $\mathrm{pH}$ is an important factor for chemical reactions and biological life in water (Alemdar et al., 2009). The specific electrical conductivity of groundwater is defined as the conductivity of one cubic centimeter of water at $25^{\circ} \mathrm{C}$. In the previous study, chemical data show that Diyadin waters were heated by magmatic activity associated with Tendurek volcano (Pasvanoglu, 2013). With every $1{ }^{\circ} \mathrm{C}$ increase in temperature, the electrical conductivity increases by $2 \%$. Electrical conductivity increases depending on the dissolved salt content of the water. The specific conductivity is expressed in microsiemens $/ \mathrm{cm}(\mu \mathrm{s} / \mathrm{cm})$ (Orgev and Inanc, 2004). In our study, the conductivity and $\mathrm{pH}$ value of only Hista thermal source were determined as $942.9(\mathrm{mS} / \mathrm{cm})$ and 9.1 . In all other sources the conductivity varied above $1000(\mathrm{mS} / \mathrm{cm})$ and the $\mathrm{pH}$ between 6.9 and 8.5 . When compared with the potable water values, it is seen in Table 1 that the thermal spring waters are outside the reference ranges. 
Iron is one of the abundant elements in the earth's crust and is one of the undesirable substances in water resources. These elements penetrate into the water as a result of erosion in the soil and rocks (Donderici et al., 2010). Ammonium has the capacity to be easily converted to nitrite first and then to nitrate under suitable reaction conditions with two-step biological oxidation. The nitrite in the environment plays an active role in the synthesis of carcinogenic nitrosamines by combining with amines and amides, which are harmful to human health. In addition, ammonium reacts with free chlorine to form chloramines (Kurama and Poetzschke, 2002). While the $\mathrm{NO}_{2}$ value ranges of the hot springs are determined as 0.254 to $0.613 \mathrm{mg} / \mathrm{L}$, the average $\mathrm{NO}_{2}$ level of the thermal springs has been reported as $0.007 \mathrm{mg} / \mathrm{L}$. When the copper $(\mathrm{Cu})$, iron $(\mathrm{Fe})$ and lead $(\mathrm{Pb})$ values in groundwater are examined, it is determined as $\mathrm{Cu}(4.3 \mu \mathrm{g} / \mathrm{L}$ and $58.8 \mu \mathrm{g} / \mathrm{L}), \mathrm{Fe}(24 \mu \mathrm{g} / \mathrm{L}-4886 \mu \mathrm{g} / \mathrm{L})$ and $\mathrm{Pb}(0.3 \mu \mathrm{g} / \mathrm{L}-$ $9.5 \mu \mathrm{g} / \mathrm{L}$ ), respectively (Aksoy et al., 2008).

Table 1. Physico-chemical parameters analysis of hot springs water samples

\begin{tabular}{|c|c|c|c|c|c|c|c|c|c|c|}
\hline $\begin{array}{l}\text { Hot Springs } \\
\text { Sources }\end{array}$ & pH & $\begin{array}{c}\text { Conductivity } \\
(\mathrm{mS} / \mathrm{cm})\end{array}$ & $\begin{array}{c}\mathrm{NO}_{2} \\
(\mathrm{mg} / \mathrm{L})\end{array}$ & $\begin{array}{c}\mathrm{NH}_{4} \\
(\mathrm{mg} / \mathrm{L})\end{array}$ & $\begin{array}{c}\mathrm{NO}_{3} \\
(\mathrm{mg} / \mathrm{L})\end{array}$ & $\begin{array}{c}\mathrm{Fe} \\
(\mathrm{mg} / \mathrm{L})\end{array}$ & $\begin{array}{c}\text { Al } \\
(\mathrm{mg} / \mathrm{L})\end{array}$ & $\begin{array}{c}\mathrm{Cu} \\
(\mathrm{mg} / \mathrm{L})\end{array}$ & $\begin{array}{c}\mathrm{Pb} \\
(\mathrm{mg} / \mathrm{L})\end{array}$ & $\begin{array}{c}\mathrm{S} \\
(\mathrm{mg} / \mathrm{L})\end{array}$ \\
\hline $\begin{array}{l}\text { Potable } \\
\text { Water Value } \\
\text { Limits }\end{array}$ & $\begin{array}{c}6,5- \\
9,5\end{array}$ & $<2500$ & $<0,5$ & $<0,5$ & $45-50$ & $<0,2$ & $<0,2$ & $<0,05$ & $<0,01$ & $<0,01$ \\
\hline $\begin{array}{l}\text { Average Hot } \\
\text { Springs } \\
\text { Limits }\end{array}$ & 7,79 & 1,899 & 0,007 & 2,15 & 38,5 & 0,377 & 0,09 & 0,5 & 1,69 & 0,02 \\
\hline Pasinler & 6,94 & 3,177 & 0,378 & 1,06 & 0 & 0,749 & 0 & 0 & 0,860 & 0,03 \\
\hline Dargecit & 6,90 & 1,782 & 0,613 & 2,39 & 2,5 & $>1,000$ & 0,134 & 8,26 & $>1,000$ & 0,039 \\
\hline Guclukonak & 7,90 & 1,146 & 0,375 & $>2,58$ & 0 & 0,925 & 0,50 & 3,19 & $>1,000$ & 0,027 \\
\hline Hista & 9,1 & 942,9 & 0,390 & $>2,58$ & 0 & 1,099 & 0,4 & 1,81 & $>1,000$ & 0,029 \\
\hline Hasanabdal & 6,2 & 5,158 & 0,395 & 0,008 & 0 & 0,389 & 0,181 & 0 & 0,666 & 0,021 \\
\hline Davut & 8,5 & 1,551 & 0,254 & 2,01 & 0 & 0,611 & 0,17 & 0 & 0,728 & 0,019 \\
\hline Kopru & 7,4 & 2,254 & 0,273 & 0,79 & 0 & 0,817 & 0,23 & 0 & 0,454 & 0,017 \\
\hline
\end{tabular}

\section{Microbial cultures}

Five different bacterial isolate (Bacillus coagulans, Bacillus licheniformis, Bacillus subtilis, Bacillus thuringiensis and Geobacillus kaustophilus) detected in the thermal springs (Ulucay, 2018) are given in Table 2 .

Table 2. Bacterial isolates of hot springs

\section{Bacteria}

\section{Regions}

\begin{tabular}{|c|c|c|c|c|c|c|c|}
\hline & Kopru & Davut & Hasanbdal & Hista & Guclukonak & Dargecit & Pasinler \\
\hline Bacillus subtilis & + & + & - & + & - & - & + \\
\hline Bacillus thuringiensis & + & - & - & + & + & + & + \\
\hline Bacillus licheniformis & + & + & - & - & - & - & + \\
\hline Bacillus coagulans & + & - & + & - & - & - & + \\
\hline $\begin{array}{l}\text { Geobacillus } \\
\text { kaustophilus }\end{array}$ & + & - & - & + & - & - & + \\
\hline
\end{tabular}


All five different isolates were identified in the water samples collected from Kopru and Pasinler hot springs. As seen in the table, B. subtilis and B. licheniformis were detected in the Davut hot spring; $B$. coagulans was observed in the Hasanabdal hot spring; B. subtilis, $B$. thuringiensis and Geobacillus kaustophilus were identified in Hista; B. thuringiensis was observed in Guclukonak and Dargecit hot springs. Savas et al. (2009) identified various thermophilic Bacillus species in the East and Southeast of Turkey from hot springs (Savas et al., 2009).

\section{CONCLUSION}

Most geothermal areas in Turkey are directly related to underground volcanism. Kopru and Davut thermal geothermal systems in Diyadin are also in contact with each other with networks where fault fractures are formed. Thermal spring waters are constantly renewed by recharging the rain water. With the flow from these cracks and fractures to the area where the major heat source is located, there is a continuous transition from rocks and soil to water. The precipitation in the studied areas penetrates deep fault and rupture zones and the waters are mixed.

Considering the temperature and various chemical values, only thermophilic microorganisms can survive here. The $\mathrm{pH}$ values determined from the springs revealed the structure that the water of the hot spring can be alkaline. According to the data got, it was concluded that all thermal springs except Pasinler have very high temperatures.

\section{ACKNOWLEDGEMENT}

This study was supported by Kafkas University Scientific Research Projects (2016-FM-24).

\section{REFERENCES}

Agaoglu, S., Ekici, K., Alemdar, S., \& Dede, S. 1999. Research on the microbiological, physical and chemical qualities of Van and its region spring waters. Van Medical Journal, 62, 30-33.

Akkaya, S. E., \& Kivanc, M. 2009. Thermophile Bacteria; Isolation and Identification Methods of GramNegative Bacillus Living in Hot Water Resources1. Electronic Journal of Microbiology TR, 7, 1-01.

Aksoy, N., Simsek, C., \& Gunduz, O. 2008. Groundwater contamination mechanism in a geothermal field: A case study of Balcova, Turkey. Journal of contaminant hydrology, 103, 13-28. doi:10.1016/j.jconhyd.2008.08.006.

Alemdar, S., Kahraman, T., Agaoglu, S., \& Alisarl1, M. 2009. Some microbiological and physicochemical properties of the drinking water of Bitlis province. Ecology, 1973, 29-38.

Baltaci, M. O., Genc, B., Arslan, S., Adiguzel, G., \& Adiguzel, A. 2017. Isolation and Characterization of Thermophilic Bacteria from Geothermal Areas in Turkey and Preliminary Research on Biotechnologically Important Enzyme Production. Geomicrobiol Journal, 341, 53-62. doi:https://doi.org/10.1080/01490451.2015.1137662.

Cetin, B., Aloglu, H. S., Harun, U., \& Karabulut, S. Y. 2016. Investigation of Water Used in Food Business in terms of Food Safety. Academic Food, 144, 375-381.

Donderici, Z. S., Donderici, A., \& Basari, F. 2010. A Research on Physical and Chemical Qualities of Spring Waters. Turkish Journal of Hygiene and Experimental Biology, 167.

Fournier, R. O. 1979. A revised equation for the Na/K geothermometer. Transactions of the Geothermal Resources Council, 3, 221-224.

Ghilamicael, A. M., Boga, H. I., Anami, S. E., Mehari, T., \& Budambula, N. 2017. Physical and chemical characteristics of five hot springs in Eritrea Journal of Natural Sciences Research, 7, 88-94.

Haki, G. D., \& Gezmu, T. B. 2012. Physico-chemical properties of waters from some Ethiopian hot springs and the risk to the health of the community. Greener Journal of Physical Sciences, 24, 138-140.

Kumar, R., \& Sharma, R. 2019. Microbial diversity and physico-chemical attributes of two hot water springs in the Garhwal Himalaya, India. Journal of microbiology, biotechnology and food sciences, 8, 12491253. doi:10.15414/jmbfs.2019.8.6.1249-1253. 
Kurama, H., \& Poetzschke, J. 2002. Membrane filtration application for removing ammonium ions from drinking water. Ecology Environment Journal, 1142, 45-48.

Mahon, W. A. J. 1970. Chemistry in the exploration and exploitation of hydrothermal systems. Geothermics, 2, 1310-1322.

Miquel, P. (1888). Monographie d'un bacille vivant au-delà de $70^{\circ}$ centigrades.

Orgev, C., \& Inanc, İ. 2004. The use of natural zeolite as a regulator of $\mathrm{pH}$, conductivity and hardness properties in natural spring waters. Biomedical Engineering National Meeting, BIOMUT. Istanbul Turkey.

Oztas Gulmus, E., \& Gormez, A. 2020. Identification and Characterization of Novel Thermophilic Bacteria from Hot Springs, Erzurum, Turkey. Current Microbiology, 776, 979-987. doi:10.1007/s00284-02001880-0.

Pasvanoglu, S. 2013. Hydrogeochemistry of thermal and mineralized waters in the Diyadin (Ağri) area, Eastern Turkey. Applied Geochemistry, 38, 70-81. doi:https://doi.org/10.1016/j.apgeochem.2013.08.010.

Pathak, A. P., \& Rathod, M. G. 2014. Cultivable bacterial diversity of terrestrial thermal spring of Unkeshwar, India. Journal Of Biochemical Technology, 5, 814-818.

Saroglu, F., Guner, Y., Kidd, W. S. F., Sengör, A., \& M, C. 1980. Neotectonics of Eastern Turkey: new evidence for crustal shortening and thickening in a collision zone. Eos, Transactions, American Geophysical Union, 6117.

Savas, S., Adiguzel, A., Inan, K., Ozkan, H., Gulluce, M., \& Sahin, F. 2009. Molecular characterization of thermophilic bacteria isolated from Van City Ercis Town Hasanabdal hot spring. Romanian Biotechnological Letters, 143, 4445-4454.

Sengor, A. M. C., \& Kidd, W. S. F. 1979. Post-collisional tectonics of the Turkish-Iranian plateau and a comparison with Tibet. Tectonophysics, 553-4, 361-376. doi:10.1016/0040-1951(79)90184-7

Simsek, S. 1997. Geothermal potential in northwestern Turkey. Active Tectonics of Northwestern Anatolia: The Marmara Poly-Project: a Multidisciplinary Approach by Space-geodesy, Geology, Hydrogeology, Geothermics and Seismology, 111.

Singh, H. K., Chandrasekharam, D., Vaselli, O., Trupti, G., Singh, B., Lashin, A., \& Arifi, N. A. 2015. Physicochemical characteristics of Jharkhand and West Bengal thermal springs along SONATA mega lineament, India. Journal of Earth System Science, 1242, 419-430. doi:10.1007/s12040-015-0550-4.

Ulucay, O. 2018. Purification, production and investigation of commercial use of 1,4- $\beta$-endo xylanase in various Bacillus species isolated from thermal resources. Kafkas University Graduate School of Natural and Applied Sciences, Doctoral Thesis (Printed).

Valeriani, F., Margarucci, L. M., \& Romano Spica, V. 2018. Recreational use of spa thermal waters: criticisms and perspectives for innovative treatments. International Journal of Environmental Research and Public Health 1512, 2675.

Valeriani, F., Protano, C., Gianfranceschi, G., Leoni, E., Galasso, V., Mucci, N., \& Romano Spica, V. 2017. Microflora Thermarum Atlas project: biodiversity in thermal spring waters and natural SPA pools. Water Supply, 184, 1472-1483. doi:10.2166/ws.2017.215. 